\title{
Erasmus, Revision, and the British Library Manuscript Egerton 1651
}

\author{
DAVID R. CARLSON
}

$\mathrm{T}$

he American writer Gore Vidal retails an anecdote about his friend, the playwright Tennessee Williams, of paying Williams a visit, only to catch him at a kind of behaviour that Vidal regarded as deviant. Williams was revising a short story that had just been published. "Why," I asked, "rewrite what's already in print?" He looked at me, vaguely; then he said, "Well, obviously it's not finished." And went back to his typing. Vidal means to make a point of Williams's obsession with working: "Tennessee worked every morning on whatever was at hand. If there was no play to be finished or new dialogue to be sent round to the theater, he would open a drawer and take out the draft of a story already written and begin to rewrite it." $B$ But the anecdote depends for its effect on an implicit agreement, between Vidal and his essay's contemporary audience, to believe that publication finishes pieces of writing, in such a way that rewriting something "that had just been published" can appear to be a pointless, neurotic occupation.

Things were different, however, before and even for some period after the advent of publication in print, which is what Vidal evidently understands by the term "publish:" well into the sixteenth century at least, Williams's behaviour would have been unremarkably normal, while Vidal's shock at the thought of revising something that had "just been published" would itself have seemed shocking. From Vidal's perspective, which he shares with his late twentieth-century audience - the perspective of a belief in the finality of print, in a fixity imparted by it to what is put into it - writers working with manuscripts of one sort and another, who were in the habit of circulating their work by means of manuscripts, appear to have been neurotic indeed about working; they were assiduous revisers and frequent republishers of work that they had already published. ${ }^{2}$

These different attitudes to rewriting seem to have something to do with the technology involved, with the material properties of book-production by 
manuscript means and by means of print; but it is in fact difficult to specify a cause. ${ }^{3}$ Texts can be stable in print, even though often they are not; but texts are not stable in manuscript, even when stability would seem to have been a desideratum. ${ }^{4}$ In the production of the text of every manuscript, human brains and hands have always participated, more and less actively; ${ }^{5}$ but the same is not so persistently true with printing and other mechanical means for reproducing writing. It is possible to make numbers of textually identical copies by means of a printing press because, once type has been set, human participation in formulating the text itself can cease. The inevitable mutability about texts circulated and reproduced in manuscript may have discouraged writers from regarding pieces of work as finished, in the way that Gore Vidal would regard something published in print as finished.

In any case, the Tennessee Williams-like attitude towards revision - the belief that "obviously it's not finished" even after publication - did not disappear with the advent of printing. It persisted among the first generations of writers to live and work in the nascent print culture of the late fifteenth and early sixteenth centuries, for whom printing was not yet synonymous with publication. Other means remained in use for making writing public; and a work's publication in any form, including print, did not obviate the possibility of its republication, subject to revision or not, by the same or different means. All that printing did was introduce an alternative means of publication for late fifteenth-century writers, without immediately precluding other means; if anything, the advent of printing may have increased textual mutability in the short term, by encouraging writers to rewrite, not only for further manuscript circulation, but also for print.

Erasmus was among those who lived and worked during this period of transition from a manuscript-dependent literary culture, characterized by textual instability, to a culture dominated by printing and the idea of textual fixity that seems eventually to have been a by-product of it. For Erasmus, evidently, printing was only an additional mode by which to circulate his writing, a mode that may have been particularly profitable for him, but one without as yet other particular privilege or particular consequences for his behaviour as writer and rewriter. He continued to avail himself of manuscript circulation for his work, publishing and republishing work to patrons and among equals in manuscript, as appropriate; and although he published in print a good deal more than most, perhaps all, of his contemporaries, his involvement with print does not seem to have made him any less assiduous a reviser of work he had already published. 
The Erasmian correspondence and his published works combine to provide an unusually great quantity of information about Erasmus's activities in publishing his work and rewriting it in public over time. The textual evolution of the Adagia, rewritten in public repeatedly over a thirty-year period, in the series of revised and redacted editions the publication of which Erasmus oversaw, only provides egregious examples of kinds of behaviour that characterize Erasmus throughout his career, including its earliest phases. ${ }^{6}$ The British Library manuscript Egerton 1651 comprises additional evidence for such practices, in Erasmus's comparatively early work as a poet. The Egerton manuscript is a collection of Erasmian writings - one rather formal letter and ten poems, one of them a poem addressed to Erasmus by the Parisian humanist Robert Gaguin - evidently written c. 1500. It attests three poems not otherwise known, and this quality has attracted some scholarly attention to it. ${ }^{7}$ But its witness to the other Erasmian writings that it includes has been undervalued; its importance is as an authoritative witness to Erasmus's activities as a rewriter of work he had already made public. The texts of the Egerton manuscript shed light on the several serial campaigns of writing and rewriting that went into the creation of these early poems of Erasmus.

Egerton 1651 is a small paper manuscript of ten leaves. It was written, without decoration or ornament of any kind, except for pen-work flourishes of the simplest sort, in a hand of c. 1500, which does not appear to be the hand of Erasmus himself. ${ }^{8}$ Copied into the book - casually, it would seem, with much abbreviation and a number of errors, only some of them corrected currente calamo by the copyist - are eleven items, all in Latin verse, with the exception of the first; the composition of none of them appears to postdate $1500:^{9}$

[1] a letter, in Latin prose, headed "Generosissimo duci Henrico Herasmus," written in 1499 in England, fols. 1r-1v (Allen, Ep. 104);

[2] "In laudem angelorum," written before early 1496, probably in Paris, fols. 1v-5r, comprising subsections headed "De Michahele," fols. 1v-3r, "Gabrielis laus," fols. 3r-3v, "Raphahelis laus," fols. $3 \mathrm{v}-4 \mathrm{r}$, and "De angelis in genere," fols. 4r-5r (Reedijk, nos. 34-37);

[3] "Hendecasillabum carmen," addressed to Robert Gaguin probably in 1495 in Paris, fols. 5r-5v (Reedijk, no. 38, "Ad Gaguinum nondum visum carmen hendecasyllabum alloquitur musas suas”); 
[4] "Epigramma Gaguini," probably contemporary with [3], fols. 5v-6r (Smith, no. 15);

[5] "In Gaguinum et Faustum Herasmus," written a few months later than [3] in Paris, fols. 6r-6v (Reedijk, no. 39, "In annales Gaguini et Eglogas Faustinas carmen ruri scriptum et autumno");

[6] "Carmen extemporale," written in 1499 in England, fols. 6v-7r (Smith, no. 9; Ferguson, p. 29; Reedijk, no. 46);

[7] "In castigationes Vincentii contra Malleoli castigatoris depravationes," written in 1498 in Paris, fols. 7r-7v (Smith, no. 10; Ferguson, p. 30; Reedijk, no. 44);

[8] "Ad Gaguinum de suis rebus," 10 written in the spring of 1496, fols. 7v-8r (Reedijk, no. 40, "Ad Robertum Gaguinum carmen de suis fatis");

[9] "Contestatio salvatoris ad hominem sua culpa pereuntem carmina futuri rudimentum," probably written in 1499 in England, fols. 8r-8v (Smith, no. 12; Ferguson, pp. 30-31; Reedijk, no. 47);

[10] "In dive Anne laudem Rithmi Iambici," probably written in 14971499, probably not in England, fols. 8v-10r (Reedijk, no. 22);

[11] "Ad Skeltonum carmen ex tempore," the first three lines only of [6] above, followed by the annotation "ut habetur," fol. 10r (Reedijk, no. 46.1-3; cf. [6] above).

The manuscript came into the collections of the British Museum Library in December 1854, having been owned previously, it would seem, by Benjamin Heywood Bright, whose books were dispersed by means of a series of sales, in 1844 and 1845, after his death. ${ }^{11}$ Nothing more can be said of its whereabouts between the time of its manufacture and the nineteenth century; but its presence in England and its English contents - the items in it written for English audiences, such as the letter to Prince Henry [1] and the poem to John Skelton [6] - foster the presumption that its provenance is English. In aggregate, the evidence supports the notion that the manuscript is a product, possibly at some remove, of Erasmus's residence in England from the early summer of 1499 until January 1500.

During this period, Erasmus's acquaintance, Thomas More, took him to meet the Tudor royal household, then in residence at Eltham. Erasmus recounted the episode some years later, in 1523, in his autobiographical letter 
to Johann von Botzheim, printed as the Catalogus lucubrationum, in which he describes the genesis of poems of his:

Sed multo prius aedideram carmen heroico hexametro et iambico trimetro mixtum de laudibus regis Henrici septimi et illius liberorum, nec non ipsius Britanniae. Is erat labor tridui, et tamen labor, quod iam annos aliquot nec legeram nec scripseram ullum carmen. Id partim pudor a nobis extorsit, partim dolor. Pertraxerat me Thomas Morus, qui tum me in praedio Montioii agentem inviserat, ut animi causa in proximum vicum expatiaremur. Nam illic educabantur omnes liberi regii, uno Arcturo excepto, qui tum erat natu maximus.

The visitors were welcomed by the royal children Henry, Margaret, Mary and the infant Edmund "in aulam;" then

Morus cum Arnoldo sodali salutato puero Henrico, quo rege nunc floret Britannia, nescio quid scriptorum obtulit. Ego, quoniam huiusmodi nihil expectabam, nihil habens quod exhiberem, pollicitus sum aliquo pacto meum erga ipusm studium aliquando declaraturum. Interim subirascebar Moro quod non praemonuisset, et eo magis quod puer epistolio inter prandendum ad me misso meum calamum provocaret. Abii dommum, ac vel invitis Musis, cum quibus iam longum fuerat divortium, carmen intra triduum absolvi. Sic et ultus sum dolorem meum et pudorem sarsi. ${ }^{12}$

In 1922, Percy Allen identified what Erasmus says he presented to Prince Henry in 1499 with the Egerton manuscript, which had come to his attention only lately: "In the British Museum," Allen wrote, "is an illuminated MS. (Egerton 1651) of ten leaves octavo, containing Ep. 104 [i.e., Erasmus's 1499 letter to Prince Henry] prefixed to a number of poems, most of which are by Erasmus. ... Though the Ms. does not contain the Prosopopoeia, it is very likely a special copy of some of Erasmus' poems prepared for presentation to Prince Henry after the visit to Eltham in the autumn of $1499 . " 13$ As the provisional nature of Allen's remarks suggests, however, identifying the Egerton manuscript with Erasmus's 1499 presentation to Prince Henry is not an altogether straightforward exercise. The basis of Allen's hypothesis is the fact that the Egerton manuscript recalls the terms used in the Catalogus lucubrationum more nearly than anything else known to survive: it does include a version of the letter Erasmus wrote Henry on the occasion, along with other English items contemporary with the letter. Nevertheless, the manuscript does not match Erasmus's account in the details that matter most. 
The Egerton manuscript is too humble to seem fit for presentation to a prince, even at short notice. ${ }^{14}$ In addition, the numerous errors of execution in the copying of the Egerton manuscript are unlikely to have been made by the author of the writings, or to have seemed passable to him without correction. ${ }^{15}$ Most to the point, the Egerton manuscript is a collection of items, comprising a representative selection of Erasmus's early verse compositions; but both the account of the presentation in the Catalogus lucubrationum and the letter Erasmus wrote Prince Henry in 1499 to cover his presentation speak as if Erasmus presented Henry a single poem, the thing of which Erasmus claims, in the Catalogus, "carmen intra triduum absolvi." In the prefatory letter that Erasmus wrote for the presentation in 1499, Erasmus again refers to his versified gift in the singular: he describes himself as a person "qui carmen suo ingenio, suis vigiliis elucubratum nomini tuo dicat," and says that he "non veritus sum hunc qualemcunque panegyricon nomini tuo nuncupare." 16 Finally, this singular carmen or panegyricon can be identified with a poem Erasmus printed repeatedly in the sixteenth century, with the title "Prosopopoeia Britanniae," a poem, unusually, "heroico hexametro et iambico trimetro mixtum," "de laudibus regis Henrici septimi et illius liberorum, nec non ipsius Britanniae." The letter with which this poem was printed in the sixteenth century does occur in the Egerton manuscript, as its first item; but the "Prosopopoeia Britanniae" itself does not, the one piece Erasmus almost certainly presented to the prince in 1499. Either Erasmus misled Botzheim in 1523, or the Egerton manuscript is not, and is not much similar to, the manuscript Erasmus presented to Prince Henry in 1499.

It is somewhat more likely that the Egerton manuscript is, or is nearly related to, another publication of Erasmus's, that the correspondence again indicates he made in England in 1499-1500. On 20 August 1499, exit from England without royal licence was prohibited, ${ }^{17}$ and Erasmus chose to pass the period of obligatory delay in Oxford. While there, between about the beginning of October 1499 until January 1500, when he returned to Paris, Erasmus stayed at St. Mary's College, the Oxford hall of his Augustinian order, the prior of which was then Richard Charnock. Charnock introduced members of the local learned community to his guest; in some measure by Charnock's good offices, Erasmus formed in Oxford at this time a number of friendships that were to remain important to him over the years, among them his friendship with John Colet. ${ }^{18}$

During this stay with Charnock, on or about 27 October 1499, Erasmus received a letter from a fellow Lowlander, who was at the time also resident 
in Oxford, Joannes Sixtinus, praising Erasmus's poetry, which Sixtinus had seen in something that Charnock had made available to him:

\begin{abstract}
Ostendit hodie mihi humanissimus dominus noster, Prior Richardus Charnocus, quaedam abs te carmina, non vulgari numero trivialive currentia; quae si multo labore confecta essent, meo tamen iudicio non in infima laude forent reponenda. Quum vero elaborata exque tempore at te conscripta dicantur, quem credis futurum, modo sit ullius ingenii, qui non te cum summis illis priscisque vatibus, perlectis tuis versibus, sit collacaturus? Redolent enim Atticam quandam venerem mirificamque ingenii tui suavitatem. ${ }^{19}$
\end{abstract}

Neither Sixtinus's letter nor Erasmus's surviving response to it - a letter in which, with an, at times, patently false modesty, Erasmus denigrates his accomplishments ${ }^{20}$ - is specific about the poetry in question. Sixtinus makes reference to a collection of poems by Erasmus ("quaedam abs te carmina," for example) that demonstrated a mastery of various metres ("non vulgari numero trivialive currentia"), some of which at least pretended to have been written "ex tempore." The collection must have been such that by it Sixtinus felt himself adequately informed to pronounce on Erasmus's skills as poet in general: that is to say, again, that the subject of the exchange of letters was a collection, and it would have to have included substantial pieces of writing.

In his reply to Sixtinus, besides simply belittling his "versiculos," Erasmus only suggests that the poetry must have been old stuff; his muses, he claims, have been enjoying ten years' rest:

Quod hortaris ut Musas meas excitem, Mercuriali virga opus esse scito, ut expergefiant ... Excitavimus nuper, et quidem iratas, a somno plusquam decenni, compulimusque liberorum regiorum laudes dicere. Dixerunt et invitae et semisomnes cantilenam nescio quam, adeo somnolentam ut cuivis somnum conciliare possit. Quae cum mihi vehementer displiceret, facile illas redormiscere sum passus. ${ }^{21}$

The implication of this reference to the "Prosopopoeia Britanniae" is that it was not among the poems Sixtinus saw; otherwise, Erasmus would not have had to describe the poem for him, the point being that the poem so extremely displeased Erasmus ("mihi vehementer displiceret") that he would not want anyone to see it. ${ }^{22}$

Because neither Erasmus nor Sixtinus is any more specific about the nature of the collection of poems that they discuss in their letters, neither quoting from nor describing or naming any of them, and there is no other evidence, it is not possible to delineate with precision the contents of the collection or 
the form that it took. ${ }^{23}$ But inasmuch as it seemed sufficient to Sixtinus for identifying the materials in question to say that he had received the collection from Charnock, Erasmus can be believed to have passed the collection to his host Charnock directly; in other words, the collection that Charnock obtained and then passed along to Sixtinus in October 1499 most likely derived immediately from Erasmian autographs. Since Erasmus was Charnock's guest at the time, Charnock may have had access to Erasmus's foul papers Erasmus's drafts of the poems, perhaps written on single, ungathered sheets of paper. These Charnock might have passed by hand, as they were, to Sixtinus, who was also locally resident at the time, and from them Sixtinus could have taken copies of his own. Alternatively, Charnock may have taken copies of the poems - all that were available to him or only selections - in a book that he could then have passed by hand to Sixtinus.

Such a process of transmission would have yielded up a thing like the Egerton manuscript, with its unauthorial errors, its apparent lacunae - its failure to incorporate the "Prosopopoeia Britanniae," along with that poem's covering letter to Prince Henry - and the confusion about its treatment of the "Carmen extemporale," which it begins to include twice. It seems somewhat more likely that the Egerton manuscript is or has its origin in such a humble, defective, confused copy, taken from Erasmus's foul papers, by Charnock or Sixtinus or some other learned Oxonian, during Erasmus's stay with Charnock in Oxford in the fall of 1499, than that the Egerton manuscript is an authorial presentation copy for a Tudor prince. But again, because of the vagueness of the evidence for what Charnock and Sixtinus saw in 1499 and the want of further evidence, it is not possible to assert unequivocally that the Egerton manuscript issued from among the circle of acquaintances Erasmus formed in Oxford in late 1499, among whom he did publish his verse.

This evidence from the Erasmian correspondence gives some idea of Erasmus's publishing activities during his time in England 1499-1500. He saw nothing printed; he had published little by this means before his arrival in England in any case, and English printers were laggard in printing humanist work. ${ }^{24}$ On the other hand, Erasmus did publish writings of his among the English, by means of manuscripts: he published a presentation manuscript to Prince Henry, probably a fairly formal thing, that seems to have comprised his just written "Prosopopoeia Britanniae" along with a letter written to cover it; and he published a collection of his poetry, probably more informally, among the circle of acquaintances he formed in Oxford.

The external evidence will not admit certainty. In the absence of additional information, however, the physical and scribal properties of the Egerton 
manuscript, its presumptive English provenance, and, most telling, the fact that the selection of Erasmus's writings contained in it includes only pieces written before 1500, the most recent of which are products of Erasmus's first English visit, all taken in light of what the correspondence reveals about Erasmus's publishing activities in England in 1499-1500, make it seem reasonable to imagine that the Egerton manuscript is a product of his activities in the country at the time. The Egerton manuscript is not the very thing that Erasmus gave to Prince Henry; it may or may not be the very thing that Johannes Sixtinus saw. It is not an autograph, authorial papers either fair or foul; but it appears to be an apograph, a copy taken, at a remove or two, though not more, from authorial papers made available by Erasmus - published, in effect - while he was in England in 1499-1500.

The internal evidence, of the textual properties of the several items in the Egerton manuscript, corroborates this view of the manuscript's origin. The details of its textual witness are discussed in some detail below; briefly, the textual evidence is that the manuscript enjoys an authority independent of the other witnesses to the several writings and attests to authorial versions and revisions of the writings. Its texts are riddled with the sort of simple mechanical error represented by the example that Allen adduced as reason for dismissing it: the reading "Stelkonum" for "Skeltonum" in the letter to Prince Henry. ${ }^{25}$ Such mistakes, numerous though they are in the Egerton manuscript, are easily recognized as such. The manuscript's non-erroneous readings, on the other hand, are not so easily dismissed, being of several sorts, in part consequent on the manuscript's texts' relations with the other sources of textual information. Differences among the Egerton manuscript texts and the other sources are often extensive, and are often too intelligent to be imputed to non-authorial meddling. In some instances, the manuscript texts give every appearance of preceding the other texts, in textual terms: in such instances, the Egerton manuscript readings, while subject to later improvement and amplification, still appear plausibly authorial, as first tries. In other instances, most tellingly, the Egerton manuscript texts are intermediate, again in textual terms, between earlier and later textual alternatives: the manuscript texts improve antecedent printed texts, in ways that bespeak Erasmus's intervention, and in ways confirmed by the later printed texts, while also retaining readings of the earlier versions that underwent further revision for the later printed texts.

Amplification is the most salient of the varieties of Erasmian revision for which the Egerton manuscript gives evidence. Three of the manuscript's items apparently antedate printed versions of the 'same' writings: the letter 
to Prince Henry [1], the "Contestatio salvatoris" [9], and in the "In laudem Anne" [10]. Comparison of the manuscript with the printed texts of these items, indicates that each underwent extensive revision, taking the form, above all, of the addition of new passages to them, at some point between their publication in the form that brought them to the Egerton manuscript and their appearance in print. Erasmus seems also to have revised by polishing his work, repeatedly. The Egerton manuscript texts of his "In laudem angelorum" [2] and the three poems for Robert Gaguin [3], [5], and [8], represent campaigns of revision intermediate between other versions of the poems, printed as early as 1496-1497, on the one hand, and then printed again in the sixteenth century, in 1503 and 1507. In these instances, Erasmus would seem to have polished his work again, each time he had occasion to publish it by some means or other. This process of repeated polishing was not altogether cumulative, however; improvements made at one stage were sometimes forgotten at the next, and sometimes retained. In any case, instead of simply republishing what he had already circulated, the evidence of the Egerton manuscript indicates that Erasmus preferred each time to publish new poems, in effect - newly refurbished versions of the poems.

In any individual instance, it might be imagined that the Egerton manuscript texts are non-authorial redactions, made from available printed materials; for example, that the manuscript's fabricator had access to the text of the letter to Prince Henry printed in 1500, and abbreviated and otherwise altered it to suit his own purposes. Such an hypothesis is more difficult to maintain in other instances: to make the Egerton manuscript texts of the epigrams for Gaguin, for example, the hypothetical fabricator would have had to have access to two printed books, and to have cobbled together his plausible texts from bits of both of them. But to suppose that the whole manuscript was made by such means necessitates imagining that the fabricator had the use of six or more printed books, published at various dates over an at least twenty-year period, between 1496 and 1518, in Paris, Antwerp, Basel, or elsewhere; that he chose from among the poetry printed in these several books only things Erasmus had written before 1500 ; and that he was able to create plausibly Erasmian new readings and to edit the disparate materials together in convincing ways. And still there would remain the problem of the Egerton manuscript's source for the two Erasmian items unique to it, the poem to Skelton [6] and the epigram for Caminade [7]. The Ockhamite alternative that the evidence will support is to believe that the texts of the Egerton manuscript derive from Erasmus's own papers, which he made available for circulation in some form while he was in England in 1499-1500. 


\section{Notes on the Egerton Manuscript Texts}

\section{[1] The Letter to Prince Henry (Ep. 104)}

By the evidence of the Catalogus lucubrationum and its own statement, Erasmus's earliest letter to Prince Henry Tudor was written during Erasmus's English sojourn in 1499, to cover his presentation to the prince of a copy of his verse "Prosopopoeia Britanniae," also written expressly for the presentation. The text of this letter in the Egerton manuscript suggests that the letter underwent revision, at its author's hands, between its original publication to the prince in the summer of 1499 and its publication in print, first in 1500, after the middle of June, and then again in January 1507, in the earliest editions of the Adagiorum collectanea. ${ }^{26}$ A number of the differences between the manuscript and printed versions of the letter are simple stylistics variants, more or less indifferent, of word order and the like; other such local variants of the printed texts, however, improve initial choices represented by the manuscript. For example, "unus vates" - the Egerton manuscript reading "eruditis carminibus praestare [immortalitatem]" is potentially confusing in ways that the reading of the printed versions, "soli vates," is not. ${ }^{27}$

More striking is the difference of length between the manuscript and printed versions: the printed versions add four wholly new passages, one which comprises about a quarter of the length of the letter as printed. Briefly, the added passages do more to flatter Erasmus than they would have done to attract royal munificence. For example, to the manuscript version's list of princely memorials that the passage of time will destroy - "incisos in es titulos et operosas pyramides" - the printed versions added "et ceras et imagines et stemmata et aureas statuas;" and the effect of the insertion is to impute excess to princely lust for glory and absurdity to such ultimately vain princely efforts to attract it.

The printed versions' longest insertions speak similarly to this issue of princely vanity. The only "glorie genus syncerius" that a prince could hope to attain, the printed versions add, is that coming to him "libero iudicio," "no ab amore, non a metu, nonab assentatione." The printed versions go on to add further that purveyors of assentatio - like Erasmus himself, in fact, who initially wrote the letter to cover his "Prosopopoeia Britanniae" - were only learned mercenaries, laughing behind the backs of the princes whom they flattered; and that modern princes were particularly susceptible to such wiles, because they were both stupid and undistinguished: modern princes "nec tamen a Gnatonibus suis laudari refugiunt, a quibus se rideri aut sciunt, si quid sapiunt, aut id si nesciunt, stultissimi sunt" - a statement which seems to leave 
potential patrons room only to choose between being dupes and being idiots - and in any case, according to the printed letter, modern princes "desierunt facere laudanda."

The longer version of the letter raises problems about relations between learned poets and their patrons - the longer version represents them as mercenary flatters and their victims, respectively - that do not come up in the shorter version. In the context of a printed book, the audience for which would in the main have been Erasmus's learned peers, the long version of the letter could suggest that Erasmus understood and stood above such venality and malfeasance. In the manuscript context of his 1499 presentation to Prince Henry, as a letter presented to a potential patron (and, in this present instance, his adult handlers), covering something so abjectly flattering as Erasmus's "Prosopopoeia Britanniae," such matters were perhaps better left unmentioned.

Here follows the text of the letter to Prince Henry in the Egerton manuscript, represented synoptically with the variants and insertions of the printed versions. ${ }^{28}$ The basic text is that of the Egerton manuscript; the punctuation is editorial; and the synoptic apparatus ignores simply orthographical variants. Egerton manuscript (Eg.) readings varied by the printed versions are italicized, and the variants are given immediately following the italicized words, the variants from the 1500 Adagiorum collectanea ( $a$, as reported in Allen) enclosed in angle brackets, and the variants from the 1507 Adagiorum collectanea ( $b$, as reported in Allen) enclosed in square brackets, often in this form: $E$ g. reading $<a$ variant [ $b$ variant] $>$; omissions of $a$ are represented by " $<>$ " and those of $b$ by "[ ]," following the words italicized in Eg. that were so omitted. Passages added to the letter by $a$ and $b$ are in boldface, enclosed in double angle and square brackets, with $a$ and $b$ variants and omissions within them italicized and bracketed above; words added by $b$ only are enclosed within double square brackets.

\section{Generosissimo duci Henrico Herasmus}

Meminisse debes, Henrice dux illustrissime, eos qui $t e<>$ gemmis aurove colunt $<$ [honorant] $>$, dare primum aliena, quippe fortunae munera, tum $<$ [preterea $]>$ caduca etiam $<$ [ ] $>$; deinde qualia possing quam plurimi mortales $<$ [quam plurimi mortales] possunt [possint] $>$ elargiri; postremo ea [ ] que tibi ipsi $<>$ domi abundent, queque donare aliis quam accipere magno principi longe sit pulchrius. At qui carmen suo ingenio, suis vigilis elucubratum nomini tuo dicat, is mihi non paulo prestanciora videtur offerre, utopote qui non aliena sed propria largiatur, nec paucis annis intermoritura; sed qu gloriam etiam uam immortalem querant $<$ [queant] $>$ efficere, tum ea que perpauci $<$ [perquam pauci $]>$ possint 
donare [neque enim pecuniosorum et bonorum poetarum par copia), et $\langle[]\rangle$ que denique non minus pulchrum sit regibus < $<$ sit regibus pulchrum] $>$ accipere quam remunerari. Et opibus quidem nemo non regum abundavit, nominis immortalitatem non ita multi sunt assequuti; quam quidem illi pulcherrimis facinoribus emereri possunt, ac unus $<$ [at soli] $>$ vates eruditis carminibus prestare. Siquidem $<<[$ [et ceras et imagines et stemmata et aureas statuas]] $>>$ et incisos in es titulos, et operosas pyramides, longa annorum series demolitur; sola vatum <[poetarum] $>$ monumenta $<<$ momenta $>$ ipsa etate, que omnia $<$ [res omnis] $>$ debilitat, invalescunt. Quod prudenter intelligens Allexander, ille cognomento Magnus, a Cherylo, poeta non admodum sane bono, singulos versiculos $<<[$ [tolerabiles]] $>>$ singulis Philippicis ex pacto redimebat. Sciebat enim $<$ Prospiciebat nimirum] $>$ et Appellis tabulas, et Lisippi statuas, paucis annis interituras, nec quicquam omnino fortium $<<$ [ [virorum] $]>>$ memoriam eternam $<<[$ posse] $]>>$ reddere preter immortalitate dignas eruditorum hominum litteras $<<[[$ nec ullum esse glorie genus syncerius ac prestantius quam quod a posteris virtuti datur hominum, non fortunae, non ab amore, non a metu, non ab assentatione, sed libero iudicio profectum]] $\gg$. Age iam, qui malos versus tam chare prodigus emit, nonne optaverit <optinent [optet]> Homericos non singulis aureis, sed singulis urbibus emercari? Quem quidem poetam, tam egregium preconem $\langle[]>,<<[$ et in deliciis habuisse, et $]]>>$ Achilli legitur invidisse $<$ [invidisse legitur] $><<[$ [beatum illum pronuncians non solum virtute, sed potissimum tali virtutum suarum precone. Quanquam non me clam est hac nostra memoria principes plerosque litteris tam non delectari quam [[eas]] non intelligunt; qui utrunque iuxta ineptum existimant, imo pudendum, optimatem virum vel scire litteras vel a litteratis laudari; quasi vero sint ipsi vel cum Alexandro, vel cum Cesare, vel omnino cum illo [ullo] veterum aut gravitate aut sapientia aut benefactorum gloria conferendi. Ineptum putant a poeta laudari, quia desierunt facere laudanda, nec tamen a Gnatonibus suis laudari refugiunt; a quibus se rideri aut sciunt, si quid sapiunt [ ], aut [[id]] si nesciunt, stultissimi sunt [sint oportet]. Quos quidem ego vel ipso Mida stolidiores iudico, qui asinis auriculis deturpatus est, non quod carmina contemneret, sed quod agrestia preferret eruditis. Mide itaque non tam animus defuit quam iudicium; at his nostris utrumque.]] $\gg . A b$ hac igitur tam generosa, tam regia Allexandri mente cum perspexissem pulcherrimam indolem tuam non abhorrere $<$ [A quorum stulticia qum intelligerem generosam tuam indolem vehementer abhorrere $]>,<<[$ d dux clarissime, eoque iam inde a puericia [nunc a puero] tuos conatus spectare ut non 
tam tuorum temporum quam veterum similis evadere cupias]] $>$, non veritus sum hoc qualecunque <[hunc qualemcunque] $>$ panegiricon tuo nomini illustrissimo <[nomini tuo]> nuncupare. Quod <[Qui] $>$ si tue celsitudini longe impar (ut est) videbitur, memineris facito et Artaxersem, regem prestantissimum, aquam a rusticano quodam operario, quam ille manu utraque haustam $\langle>$ obequitanti obtulerat, hilarem subridentemque accepisse, et eiusdem nominis alterum $<$ alium $]>,<<[$ [ut opinor, ]] $>>$ pro malo a pauperculo quopiam allato, perinde ut pro mangificentissimo munere, gratias egisse, ratum videlicet non minus esse regale, parva prompte accipere, quam magna munifice elargiri. Quinetiam superos ipsos $<$ QQuid? Nonne etiam superi ipsi] $>$, qui nullis mortalium opibus <operibus $>$ egent, $<<[$ [ita muneribus [[huiusmodi]] delectantur ut]] $\gg$ contempta interim divitum hecatombe, rusticana mica et thusculo $<<[$ [paupere] $]>>$ placari $<$ [placentur] $>$, nimirum offerentis animo $<$ [animo nimirum offerentis] $>$, non rerum precio, nostra donaria metiaris $<$ [metientes $]>$. Atque $<[\mathrm{Et}]>$ hec quidem interea tanquam ludicra munuscula tue puericie dicavimus, uberiora largituri ubi tua virtus, una cum etate accrescens, uberiorem carminum materiam suppeditabit. Ad quod equidem te adhortarer, nisi $<<[$ et $]]>>$ ipse $<<[$ iamdudum] ] $>>$ sponte tua velis remisque $<<[$ [ut aiunt]] $>>$ eo tenderes, et domi haberes Skeltonum, unum Britannicarum litterarum lumen ac decus, qui studia tua $<$ [tua studia] $>$ possit non solum accendere verum $<$ [sed] $>$ etiam iuvare $<$ [consummare $]>$. Bene vale $<<[$ [et bonas litteras splendore tuo illustra, auctoritate tuere, liberalitate fove $] \mid>>$.

\section{[2] The "In laudem angelorum" (Reedijk nos. 34-37)}

Erasmus's carmina in praise of the angels - a single work comprising a series of subsections - was apparently commissioned, for use in a chapel. As it happened, the work was not used in the chapel as intended, ${ }^{29}$ and the date of the commission remains uncertain. The work has been thought to be a product of Erasmus's residence in Paris in the autumn of 1495, but it may in fact be earlier. ${ }^{30}$ In any event, the work was printed at Paris in 1496, under Erasmus's superintendence, among other early poetry of his in a volume entitled De casa natalicia Jesu, Erasmus's first publication in print. ${ }^{31}$ Texts of the work also occur as the second item in the Egerton manuscript, and in a series of sixteenth-century printed books: the Lucubratiunculae aliquot printed by Schurer at Strasbourg between September 1515 and November 1517,33 and the Epigrammata and Enchiridion militis christiani printed by Froben at Basel in March and July 1518, respectively. ${ }^{34}$ 
The text of the work in the Egerton manuscript, here entitled "In laudem angelorum," is filled with numerous simple errors, apparently purely mechanical mistakes made by the manuscript's copyist (e.g., at 34.11, 34.51, 34.53, $34.82,34.87,35.19,35.25,35.28,35.34,36.3,36.13,37.18$, and the transposition of hoc and haec at 37.33). The other early text of the poem, that printed in 1496 in the De casa natalicia, manifests a similar rate of mechanical error on the part of compositors involved in its production. Except in four instances, of orthographical variation that seem likely to have occurred independently in both the 1496 and the Egerton manuscript never perpetuates the errors of the 1496 text. Rather, as does the rest of the subsequent textual tradition, the Egerton manuscript, even while introducing its own peculiar errors, regularly corrects the 1496 errors (e.g., at 34.57, 34.60, 34.67, 34.72, 35.6, 35.11 [bis], $35.18,35.55,36.11,36.20,37.30,37.35,37.43)$.

The Egerton manuscript introduces errors of its own; but it also corrects errors of the antecedent, 1496 text, and it attests independently of the antecedent text a series of seemingly authorial changes to the poem that recur also in the later printed editions. Six readings of the 1496 text that are plausible, i.e., non-erroneous and not patently unauthorial readings, change in the later printed editions (at 34.33, 34.39, 34.54, 34.93, 37.21, and 37.31). The nature of these differences between the 1496 texts and the later printed editions necessitates presupposing intelligent, creative, i.e., most plausibly authorial, intervention in the work; and each of these plausibly authorial revisions or corrections that appear in the printed editions of 1503 and later occurs also in the Egerton manuscript.

In addition, the Egerton manuscript "In laudem angelorum" has some eighteen plausible readings that are unique to it, non-erroneous readings that occur in neither the fifteenth- nor the sixteenth-century printed texts. Of these plausible readings unique to the Egerton manuscript, one is probably a worse reading than that of the printed texts (37.21); nine are more or less indifferent from the readings of the printed texts (i.e., 34.7, 34.61: metuant, 34.77, 35.17, 35.31, 37.7, 37.25, 37.33: Querit and 37.73) - no reason for preferring the one over the alternative is apparent in these cases; and in the remaining eight instances, the unique Egerton readings appear preferable, on some stylistic basis or other $(34.81,35.42,36.10,36.11$ : multis, 36.17, 36.32, 37.49-60, and the manuscript's subtitles). Minor instances of such preferable unique Egerton readings include "ferus ille," in place of "metuitque" at 35.42, where the Egerton reading reduces the number of finite verbs and conjunctions, which otherwise clutter the stanza (35.41-44: "Vidit obliquis oculis volantem/ Dextero celo metuitque latis/ Incubans terris draco luridoque/ 


\section{4 / Renaissance and Reformation}

Palluit ore"), as well as introducing a pointed contrast between the "ferus ille ... draco" and the fear the angel's approach awakens in him; likewise, the Egerton reading "Rectius nos te colimus," in place of "Nos magis nos te colimus" at 36.17 , where the Egerton reading eliminates a pointless emphasis on the verb's subject.

The most significative of these unique Egerton variants is the manuscripts treatment of the poem's subsections. ${ }^{35}$ All texts concur in providing a single general title for what turns out to be a poem built of more or less discrete sections. The 1496 text sets at the beginning of the poem: "Carmen ad orationem solutam plurimum accedens: Ode dicolos hendecasyllaba Sapphica in laudem beatissimorum angelorum feliciter incipit;" under this rubric follow a first section headed "Invocatio propositionem complectens" (equivalent to Reedijk's no. 34); a second section headed "De singulari laude Gabrielis Archangeli" (Reedijk's no. 35); a third section headed "De singulari laude Raphaelis" (Reedijk's no. 36); and a fourth section headed "De universis angelis" (Reedijk's no. 37). The difficulty with this 1496 arrangement is that, although most of the ninety-six lines of verse in its disproportionally long first section are devoted to praise of St. Michael, as subsequent sections are devoted to praise of other angels, the heading of the section, "Invocatio propositionem complectens," does not mention him. The 1496 editions' failure to distinguish the poem's "Invocatio," which the 1496 title does mention, from a subsection in praise of Michael, that the 1496 title does not mention as such, is repeated in all subsequent editions. The later printed editions, of 1503-1518, address this problem in part, by offering as title for the whole: "In laudem Michaelis et angelorum omnium," and by omitting to mention or distinguish the "Invocatio" with which the poem begins. But only the Egerton manuscript's treatment of the whole poem and its subsections meets the work's internal requirements: it calls the whole "In laudem angelorum," and it sets the "Invocatio" (= Reedijk 34.1-16) apart from a section in praise of Michael (= Reedijk 34.17-ad finem) by inserting the subtitle "De Michahele" between the two; for the poem's other three subsections, on Gabriel, Raphael, and all angels, the Egerton manuscript adheres to the practices of the printed editions, setting off each from the others with subheadings.

Inasmuch as the Egerton manuscript elsewhere independently attests plausibly authorial revisions of the "In laudem angelorum" that the later printed texts confirm, it is at least possible that these other non-erroneous readings unique to the Egerton manuscript may also be authorial revisions, but ones not attested by the later printed tradition for some reason or other. Over half of the unique Egerton readings are at least as good as the readings of the rest of the tradition; some seem fairly clearly to be improvements over the texts 
transmitted in printed editions; and one of them - the manuscript's representation of the thing as a single whole poem, entitled "In laudem angelorum," subdivided into a sixteen-line proem and four additional sections, on Michael, Gabriel, Raphael, and all angels - seems to capture authorial intention like no other representation of the work.

The evidence suggests that the original version of Erasmus's poem, of about 1495, represented only imperfectly by the printed editions of it of 1496 , subsequently underwent revision and correction. A comparatively more thoroughgoing correction and revision of it is attested by the Egerton manuscript; and because this campaign of work on the poem is so attested, it probably would have taken place prior to or during Erasmus's visit to England in 1499. An independent, less thoroughgoing but in the event not altogether different set of revisions and corrections of the 1496 original was later made, and appears in the later printed texts, beginning in 1503. The earliest revised printed text, of 1503, was probably produced from a marked-up copy from one of the 1496 printed editions, without access to or complete recollection of anything like the Egerton manuscript text, and it incorporates only a simpler sort of correction and revision; the more substantive and extensive of the revisions attested by the Egerton manuscript remained otherwise unattested.

Here follows a collation of the Egerton manuscript variants, excluding variants of orthography, for the "In laudem angelorum," with the texts as printed by Reedijk, the Egerton readings following the bracketed lemmata. ${ }^{36}$ Variants marked with an asterisk were not reported by Reedijk.

*Tit.] In laudem angelorum 34.1 Michaele] Michael 34.7 fulgente] stellante *34.11 Applicet] Applice *34.13 Luridae] Luride inter 34.1617 ponit Eg. De Michahele 34.23 Utve] Utque $* 34.39 \mathrm{olim}$ ] idem exciebis] excitabis *34.51 Fulminisque] Fulminis *34.53 terret] terre 34.54 Beluae] Bellue 34.61 Ergo] Deinde trepident] metuant 34.77 Laetus idcirco] Ergo certatim 34.81 celebrantur] referuntur $* 34.82$ res] des $* 34.87$ terimus] terminus 34.90 vocablum] vocabulum *inter 34.96 et 35.1 ponit Eg. Gabrielis laus 35.17 canendo] canentes $* 35.19$ nih] nihil $* 35.25$ Tum] Tu *35.28 Deligit] Delegit 35.31 ne ille sciscat] sentiat ne $* 35.34$ placido] placito 35.42 metuitque] ferus ille inter 35.60 et 36.1 ponit $E$ g. Raphahelis laus $* 36.3$ Tu te] Tute 36.10 multa] longa $* 36.11$ ac longis] multis 36.13 Phoebumque] Phebum 36.17 Nos magis] Rectius inter 36.24 et 37.1 ponit $\mathrm{Eg}$. De angelis in genere 37.7 plenam] pulchram 37.17 quondam] quoniam 37.18 rutilabat] rutilabit 37.21 Iam pares] Compares 37.32 Decidit] Depluit 37.33 Pugnat] Querit hoc] hec haec] hoc *37.35 tundat] tondat 49-60] 57-60, 49-56 37.72 Christigenarum] Christicolarum 
[3], [4], and [5] The three Parisian epigrams (Reedijk, no. 38; Smith, no. 15; and Reedijk, no. 39)

The texts of these three epigrams transmitted in the Egerton manuscript appear to stand halfway between original versions and the versions printed in the early sixteenth century. The poems - two by Erasmus, [3] and [5], and one by Robert Gaguin, [4] - would most likely have circulated hand to hand in Paris, in ephemeral manuscript copies, in the period just after Erasmus's arrival in Paris, by September $1495,{ }^{37}$ at least among Erasmus, Gaguin, and Fausto Andrelini, the third party immediately interested in them. The epigram by Gaguin does not seem to survive otherwise than in the Egerton manuscript ${ }^{38}$ but fairly soon after their first composition and circulation, the two poems by Erasmus were printed in 1496, in Erasmus's De casa natalica collection, along with the "In laudem angelorum" and other pieces. These 1496 texts appear to be the earliest extant ones of the Erasmian poems, but they are not the only printed ones; the poems were reprinted in different versions, among Erasmus's collected epigrammatic verse in the 1507 Adagiorum collectanea printed by Bade at Paris and again in the 1518 Epigrammata printed by Froben at Basel. The Egerton manuscript texts of Erasmus's two poems share with the 1496 texts some eight readings, all them plausible, probably authorial readings, that were later changed when the poems were reprinted in the sixteenth century $(38.3,38.4,38.24,39.3,39.15$, $39.26,39.31$, and 39.32-33). ${ }^{39}$ Most telling of these is perhaps the absence from the 1496 text and the Egerton manuscript of an entire couplet (treated by Reedijk as 39.32-33) and the revision of the end of the preceding line (39.31) necessitated by the insertion of the couplet in texts of 1507 and later. The passage in the 1496 and the Egerton manuscript texts reads:

Ille quidem felix agit ocia, sed Scipionis

Ocia, pulchri plena negoci.

while in the sixteenth-century printed editions it reads:

Ille quidem felix agit ocia, qualia quondam

32 Scipiades agitare solebat

33 Urbe procul tacitis solus, neque solus, in agris,

Ocia pulchri plena negoci.

(Reedijk, 39.31-34)

Both versions of the passage are satisfactory, but the later version by no means represents careless or casual alteration of the earlier one. The new couplet, in 
the altered setting, appears to be a revision of the 1496 version of the poem that had not yet been made by the time of the genesis of the Egerton manuscript; the other readings similarly shared between the 1496 and Egerton texts in contrast to the later printed texts - albeit that they are less substantive variants and consequently admit discrimination less surely - are probably similarly changes made to the poems only comparatively late.

The Egerton manuscript also has a dozen readings unique to it, not counting its treatment of the titles of the poems, which each of the texts treats differently from all of the others. Seven or either of these unique readings represent results of simple mechanical error, almost certainly due only to the peculiar competence of the person who wrote the Egerton manuscript and so are of no textual import $(38.25,39.2,39.6,39.13,39.47,39.49,39.51-52$, and possibly 39.25). The rest are minor variants, of single terms $(39.35,39.36,39.40$, 39.59 , and, again, possibly 39.35). The best of them, which tends to suggest that at least some of these unique Egerton readings are authorial, is the replacement of the redundancies of the phrase "vagus errat" with the (admittedly unclassical) "correptat" (39.36); in any case, all of these unique, non-erroneous Egerton variants are of a sort that would appear to have been created more or less casually, but with some care and thought, in the process of recopying the poems. None of these peculiarities of the Egerton manuscript seems to have been of sufficient significance - granted for the moment that they are authorial - to have been remembered when the poems were being prepared for republication later among Erasmus's other epigrams.

Such was not the case, however, with the preponderance of the Egerton manuscript's differences from the 1496 texts. In thirty-one instances, the Egerton manuscript offers readings differing from those printed in 1496, that did then reappear in the printed texts of the sixteenth century $(38.5,38.9$, $38.11,38.27,39.1$ [bis], 39.5, 39.9, 39.11 [bis], 39.12 [bis], in omitting the couplet that in 1496 followed 39.12, 39.13 [bis], 39.17, 39.22, 39.23, 39.27, $39.35,39.39,39.43$ [bis], 39.44, in adding the couplet 39.47-48 that had not occured in $1496,39.49,39.56,39.57,39.59,39.60$, and in omitting the couplet that in 1496 had followed 39.60 to conclude the poem). ${ }^{40}$ No more than five of these readings shared between the Egerton manuscript and the texts in later printed collections of epigrams simply correct evident errors of the 1496 texts (39.17, probably 38.5 , and possibly the variants of word order of 39.57 and 39.59-60); the rest are substantive revisions to the versions of the poems printed in 1496, including several that involved rewriting whole lines and couplets (e.g., following 39.12, at 39.27, 39.35, 39.39, 39.44, 39.47-48, and following 39.60). The better part of the final versions of these poems - the 
versions in the sixteenth-century printed collections of Erasmus's epigrams - made its earliest appearance in the Egerton manuscript.

Erasmus's epigrams for Gaguin and Andrelini survive in three versions, each with its own integrity, and each evidently authorial. The original versions are attested by the 1496 printed book; and the final versions - final in the sense that Erasmus cannot be shown to have fiddled with the poems any further - appeared first in 1507, when Erasmus first saw printed his collected epigrammatic verse. Between these two publications in print, Erasmus would seem to have circulated intermediate versions of the poems, as attested by the Egerton manuscript. Albeit impossible to be conclusive about the date of the Egerton manuscript - its exact chronological fit between or otherwise in relation to the printed books of 1496 and 1507 - the manuscript is in textual terms intermediate between them, sharing textual features with both. The intermediate versions attested by the Egerton manuscript perpetuated a comparatively small number of features otherwise distinctive of the 1496 versions, while also changing the 1496 versions extensively. The final versions perpetuated the better part of the revisions introduced at the intermediate stage; effectively discarded a few minor readings, which by consequence remained peculiar to the intermediate versions; and introduced additional, albeit comparatively few, changes of their own, altering some passages that the intermediate versions had retained from 1496. The greatest difference is between the initial and intermediate versions, between which the greatest amount of revisions was done; the final versions represent only a comparative minor retouching of the intermediate versions for republication.

Again: here follows a collation of the Egerton manuscript variants, excluding variants of orthography, for Erasmus's epigrams for Gaguin and Andrelini, with the texts as printed by Reedijk, the Egerton readings following the bracketed lemmata. ${ }^{41}$ Variants marked with an asterisk were not reported by Reedijk.

*38.Tit.] Hendescasillabum carmen 38.3 trepidaeque pallidaeque] trepideque pallideque post corr. 38.4 Necnon Parmeno uti] Ac Parmeno velut 38.24 ille] ore 38.25 ] deest

*39.Tit.] In Gaguinum et Faustum Herasmus *39.2 in herbal desunt *39.3 Errabam] Errarem $* 39.6$ peroso] perose $* 39.13$ occupo] occupe $* 39.15$ devinctus] devotus 39.25 ipsi] illi $* 39.26$ ac] atque 39.31 qualia quondam] sed Scipionis $39.32-33$ ] desunt 39.35 Quippe] Nunc 39.36 vagus errat] cooreptat 39.40 Agresti] Buccolica $* 39.47$ placidos] placidas *39.49 tecum] demum 39.51-52] desunt 39.59 arundine] Appolline 
[6], [7], and [11] The "Ad Skeltonum carmen" (Reedijk no. 46) and the Vergilian Epigram (Reedijk no. 44)

Besides Robert Gaguin's epigram to Erasmus and Fausto Andrelini, two other poems are known only from the Egerton manuscript. The one is a poem addressed to and in praise of John Skelton, written out in full following Erasmus's epigram to Gaguin and Andrelini, under the title "Carmen extemporale" [6], the first three lines of which, followed by the annotation "ut habetur," were again copied out at the end of the manuscript, under the title "Ad Skeltonum carmen ex tempore" [11]. The other is an epigram in the voice of Vergil [7] - who praises the work of Augustin Vincent Caminade, and damns that of Paul Hemmerlin, ${ }^{42}$ on the text of his poetry - copied out following the "Ad Skeltonum."

Both poems appear to have been written in the fifteenth century, the Vergilian epigram in $1498,{ }^{43}$ and the "Ad Skeltonum," extemporaneously according to its titles, during Erasmus's English sojourn in 1499-1500. The Vergilian epigram was occasioned by the publication of a pair of rival editions of Vergil at Paris in the same year, 1498, the one by a person - Caminade on whom Erasmus was financially dependent from time to time, during the period July 1497 - December 1500 . The epigram would have served to repay Caminade, for benefactions done to Erasmus, and to strengthen the association between them. Probably, it first circulated in Paris more or less privately, passed hand to hand in ephemeral manuscript copies, posted publicly, or inscribed in copies of the book in question. Its subsequent republication, by means of its inclusion in a collection like the Egerton manuscript, would have served to give notice to such a collection's English audience of the extent of Erasmus's Parisian connections, as do also the suite of epigrams included in the collection that had passed among Erasmus, Gaguin, and Andrelini in Paris.

The "Ad Skeltonum" appears to have been similar in purpose, albeit different in occasion: something written to ingratiate Erasmus with Skelton. Skelton was Prince Henry's tutor during Erasmus's first visit to England, a position carrying with it some status and influence, and Skelton was present in this capacity when More brought Erasmus to visit the royal household at Eltham in 1499.44 Erasmus's "Prosopopoeia Britanniae," also written extemporaneously, and certainly occasioned by this visit to Eltham palace, also makes mention of Skelton, likewise in flattering terms. But there is no evidence of any contact between Erasmus and Skelton subsequent to their meeting in 1499.

Both the Vergilian epigram for Caminade and the effusion for Skelton would appear to have served short-term local ends for Erasmus, to earn 
himself the favour of the two men, each of whom was already comparatively well established, in a locale in which Erasmus was seeking a place for himself. After 1498-1499, Erasmus' financial situation improved and his reputation grew, whereas Caminade remained obscure and comparatively impoverished, and Skelton lost his standing at court when he left the royal household in about 1502. The inclusion of these two apparently early poems of Erasmus in the Egerton manuscript makes most sense, then, if the manuscript is early, or represents a collection of Erasmian pieces assembled early in his career, by about 1500. After that date, interest in the two poems, on the part of Erasmus or anyone else, would have been minimal; in fact neither of the poems was put into print, by Erasmus or anyone else, until 1923. ${ }^{45}$

Nothing needs be added to the representations of these poems in Smith (whose edition is most like the manuscript, except that he gives "Castaldumque" in place of ms. "Casthalidumque" at 46.4 and "Apollo" in place of ms. "Appollo" at 46.8), in Ferguson and Reedijk (who classicize and otherwise "correct' the orthography), and in Vredeveld, "Erasmus' Poetry," pp. 156-157 and 159-160; except to note that the text of 46.1-3 recopied at the end of the manuscript (i.e., item [11]) does not differ from the other copy of it in the manuscript (i.e., the first three lines of item [6]); the peculiar title given the three-line fragment here and the note at the end of it are quoted above.

[8] The "Ad Gaguinum de suis rebus" (Reedijk no. 40)

Like the other poems in the Egerton manuscript for or by Robert Gaguin, the poem later printed as the "Ad Gaguinum de suis fatis querela" was written fairly soon after Erasmus's first arrival in Paris. Since it was not included in the De casa natalica collection, along with Erasmus's other poems for Gaguin, printed in Paris in January 1496, the poem is presumed to postdate that publication; other evidence suggests that it had probably been written by May 1496, when a personal copy would have been provided Gaguin, and other manuscript copies may have circulated hand to hand as well. ${ }^{46}$ In any event, the poem was printed in January 1497 with the Sylva odarum of Willem Hermans - a long-time friend of Erasmus - a volume which Erasmus edited, also contributing a dedicatory letter to it, addressed to Henry of Bergen and dated from Paris 7 November $1496 .{ }^{47}$

There is little in the surviving textual evidence to suggest that Erasmus (or anyone else) ever much reworked this poem, at any point after its initial composition and printed publication in January 1497. The four at least potentially authorized and authoritative texts of the poem - those in the 1497 
Hermans Sylva Odarum, in the Egerton manuscript, in the 1507 Adagiorum collectanea, and in the 1518 Epigrammata - differ from one another only incidentally. In the poem's fifty-two lines, there are differences among the four texts at only fourteen places; with the exception that the 1497 text apparently twice omits whole lines, these differences among the four texts are never matters of more than single words. Furthermore, nine or ten of the fourteen variants are mechanical errors, of some copyist or compositor (40.6, $40.22,40.26,40.28,40.32,40.46$ [bis], 40.47, 40.52, and probably 40.24); those that remain - differences between ned, non, and neque $(40.8,40.9)$, and between toties and totiens (40.26) - may well be mechanical errors too, and are not in any case intrinsically interesting, nor informative, with the possible exception of an Egerton manuscript variant in a line omitted from the 1497 publication.

Here as elsewhere, the Egerton manuscript introduces its own errors into the text (e.g., 40.6, 40.22), but at the same time it also corrects errors of its antecedent, in this instance, the 1497 printed text (40.28, and possibly also 40.9 and 40.24). Most informatively, the Egerton manuscript supplies, evidently out of its own resources, two lines that do not occur in the 1497 text, but which do appear in the sixteenth century editions (40.47 and 40.52) ${ }^{48}$ in one of them, the Egerton manuscript reads "Nec cedent miseris pectora casibus" where the later printed editions read "gravibus" (40.52). Neither of the lines could have reached the Egerton manuscript via the 1497 edition, and the variant version of the one could not have come to it from the sixteenthcentury editions. The Egerton manuscript is not the earliest of the texts of the "De suis fatis;" if it antedates 1507, as seems probable, it is the earliest complete text of the poem, supplying the lines omitted in 1497; in any case, the manuscript's ability to supply the two lines, in the form in which it does, again bespeaks an independence from other sources of textual information and an independent access to authoritative documents.

Again: here follows a collation of the few Egerton manuscript variants in the "De suis fatis," excluding variants of orthography, with the texts as printed by Reedijk, the Egerton readings following the bracketed lemmata. ${ }^{49}$ Variants marked with an asterisk were not reported by Reedijk.

*40.Tit.] Ad Gaguinum de suis rebus *40.6 teneras] teneas *40.8 Nec] Non $* 40.22$ certo] certe $* 40.25$ Sullae] Scylle $* 40.26$ toties] totiens 46 Quaeve] Quove *40.52 gravibus] miseris 


\section{[9] The "Contestatio salvatoris" (Reedijk no. 47)}

It is generally recognized that a verse monologue, in the voice of Christ, who chastizes humankind's neglect of him, exists in two versions by Erasmus, a short form, the "Contestatio Salvatoris ad hominem sua culpa pereuntem," which occurs in the Egerton manuscript, and a longer one, the "Expostulatio Iesu cum homine suapte culpa pereunte" (Reedijk, no. 85), repeatedly put into print in the sixteenth-century. ${ }^{50}$ In kind, the differences between the "Contestatio" and the "Expostulatio" are similar to those between other Egerton manuscript versions and the cognate printed texts, embracing both large-scale changes and local stylistic improvements. The most substantive differences between the two versions are reflected in their lengths; like the printed version of the 1499 letter to Prince Henry, the printed "Expostulatio" is an amplification of the "Contestatio," a thing about three times as long again. The order of lines of the "Contestatio" was kept intact, and among the original lines were inserted a series of wholly new passages, including a passage of sixteen lines subjoined after what had been the end of the thing in the short version (85.75-90).

Only five lines of the "Contestatio" (47.3-4, 13-14, and 19) were wholly discarded from the "Expostulatio;" eleven of the twenty-eight lines of the short version differ not at all from their counterparts in the longer poem $(47.8$ $=85.20,47.10-12=85.22-24,47.15-16=85.31-32$, and 47.24-28 = 85.70$74)$; the rest were variously altered, much or only slightly. In most instances, these local alterations functioned to refit the old lines for reuse in contexts created by the new lines; in others, however, the changes appear to be considered improvement, that is, to represent the sort of verbal polishing that other poems of Erasmus seem also to have undergone for appearances in print. For example, the printed editions' phrase "implacabilis ulto iniqui" (85.67) is more precise in meaning than the Egerton manuscript's "vindexque severus iniqui" in the cognate line (47.23); and its verbs "rapit" and "ardet" (85.1112) are more vivid and emphatic than the verbs in the same couplet of the shorter version: "capit" and "amat" (47.5-6). ${ }^{51}$

The long version made its first known appearance c. 1511, in a printed book comprising a series of poems that Erasmus wrote at the behest of John Colet, for use in Colet's recently edified St. Paul's School; this set of poems "in schola Coletica pronuncianda," including the "Expostulatio," was thereafter frequently reprinted, in editions authorized and corrected by the poem's author. ${ }^{52}$ The short version survives only in the Egerton manuscript, and its occurrence here tends to suggest an early date of composition for it, relative to the printed editions of c. 1511 and later: the poems attested uniquely by the 
Egerton manuscript are all early ones, written in the fifteenth century, and none of the other Egerton manuscript writings that were put into print would appear, by the internal, textual evidence, to be later than the first decade of the sixteenth century. The nature of the difference between the "Contestatio" and the "Expositio" likewise suggests that both versions and their publication originated in Erasmus's initiative, and that the short version is in the earlier version, the basis for later amplification and subject to authorial polishing. The subtitle given the "Contestatio" in the Egerton manuscript - "Carminus futuri rudimentum" - tends to confirm the implication of the textual evidence, that the short version, an authorial version, came first. The information that the "Contestatio" was "carminus futuri rudimentum," the groundwork, in effect, for a poem yet to be, can only have come from Erasmus, an author conscious already at the time he circulated the "Contestatio," of an intention to rework it, to make of this rudimentary draft something greater.

The Egerton manuscript text of the "Contestatio" has already been reported thoroughly, by Smith, Ferguson and Reedijk; the following cautionary remarks only seem called for. Smith's is here again the most diplomatic text. The last word of the title is "rudimentum," not "rudimenta:" the first word of the poem seems certainly, by light of scribal practice elsewhere, to be "Qum," not "Quin;" and the manuscript regularly spells "qum" and "qur" $(47.1,8,17,18,20)$ what Smith gives as "quum" and "quur," and Ferguson and Reedijk give as "cum" and "cur." The manuscript's reading at 47.6 is "hac," which all have corrected silently to hanc; and, contrary to what Reedijk reports, 47.11 reads "sapiencia" (as also in the cognate line 85.23) rather than "patientia." 53

[10] The "In laudem Annae" (Reedijk no. 22)

Erasmus's poem in praise of St. Anne, mother of Mary, the "In laudem Annae," was a presentation piece for Anna van Borssele, Lady of Veere. Erasmus visited her at Tournehem before visiting England in 1499-1500, and probably again just after; ${ }^{54}$ his friend Jacob Batt was in her household, as her son's tutor, and Erasmus continuously entertained hopes of benefitting from her patronage, up until the time of her remarriage and Batt's death in 1502.55 He presented the poem to her with a dedicatory letter dated January 1501; but the poem was not printed for some years, until 1518, when, in March, it was printed by Froben in the Epigrammata and, in July, it was reprinted, again by Froben, in the first edition of the Enchiridion.

In the dedicatory letter addressed to the Lady Anna, with which he prefaced the poem, Erasmus claimed that the "In laudem Annae" was "carmen vel rithmos potius a me puero admodum lusos; nam iam inde a tenellis unguiculis 
eius Divae pietate flagravi." 56 The claim may be compounded of disingenuous flattery in some part; it might also, on the other hand, be true that, by 1501 , the poem had already been in existence for some time, ${ }^{57}$ and the extant textual evidence indicates that the poem underwent revision at some point in the course of its publication history.

The text of the "In laudem Annae" printed and reprinted in 1518 differs from that transmitted by the Egerton manuscript, particularly significantly at the poem's conclusion. There are only about a dozen differences between the manuscript and the printed texts, and five to seven of these are evidently mechanical errors of transmission $(22.31,22.38,22.52,22.65,22.74$, and probably 22.39 and 22.68 as well). For the rest of the variants involving single words or brief phrases, the readings of the printed texts appear to be improvements, by comparison with the basically sound readings of the Egerton manuscript (22.12, $22.35,22.57$, and 22.63). For example, in the phrase "hinc leti lares/ Iunctis revisunt gressibus" (22.63), the "leti" of the manuscript is replaced by "modicos" in the printed editions, a reading that yields a metrically more supple line as well as giving greater point to the passage. Of course, the angel's announcement of Anna's pregnancy would make the aged couple leti; "laetus stupor" of the previous line but one (22.61) is the more striking image for their response, and to repeat the same term two lines later only detracts from its effect; moreover, the couple's humility - their return to their "modicos lares," even as exalted as the angel's visit has made them - is a point worthy to bear some emphasis, for purposes of moral doctrine.

The difference of greatest substance, between the manuscript and the printed texts, occurs at the poem's conclusion. In the printed versions, the "In laudem Annae" ends with a question and a twenty-line answer to it:

Fit Anna filiae parens,

Nec filiae cuiuslibet,

Sed filiae quae fertilis

Eademque virgo gigneret.

At quem beata gigneret?

Summi parentis filium,

Qui sceptra terrae et aetheris

Cum patre habet communia

(22.71-78)

and so forth, at some length. The Egerton manuscript text neither asks nor answers the question, wanting the interrogatory line as well as the bulk of what follows it, to conclude more summarily: 
Sed filiae quae fertilis

Eademque virgo gignere $<\mathrm{t}>$

Summi parentis filium.

The conclusion of the printed texts only amplifies the paradoxes of the faith already articulate at the end of the manuscript versions, those of the virgin birth, of a son who is also his parent's parent, with a focus on the Virgin and on Christ not otherwise apparent in Erasmus's poem about St. Anne. In the absence of the printed texts, there would be no reason to suspect defects about the concise ending that the manuscript puts to the poem, which is coherent as its stands. ${ }^{58}$

It is difficult to place the making of these changes to the poem in time - the local verbal improvements and the amplification of its conclusion. The Egerton version may be juvenile version of the poem to which Erasmus seems to allude in his letter to Anna van Borssele, which Erasmus improved and amplified before presenting it to her in 1501 . The alternative is to imagine that the Egerton manuscript version is essentially the same version as was presented to Erasmus's prospective benefactor in 1501, and the revisions may have been made considerably later, with a view to printing the poem, as was done in 1518. In either case, the textual evidence favours an hypothesis of the circulation of two versions of Erasmus's "In laudem Annae," a briefer one circulated at least in England in 1499-1500, whereby it could have come to the Egerton manuscript, and an amplified one, printed in 1518, one or the other of which was also published by presentation to Anna van Borssele in 1501; the evidence is that, after an initial publication of it in one form, Erasmus reworked his poem on St. Anne and published it again in a different form.

Again: here follows a collation of the Egerton manuscript variants, excluding variants of orthography, for the "In laudem Annae," with the texts as printed by Reedijk, the Egerton readings following the bracketed lemmata. ${ }^{59}$ Variants marked with an asterisk were not reported by Reedijk.

22. Tit.] In dive Anne laudem rithmi iambici $* 22.12$ Deus] decus 22.31 mihi] deest 22.35 Vestran] Isthec 22.38 libidinem nihil] nihil libidinem ac 22.39 et] deest $* 22.52$ probe probrum] prole proborum 22.57 invicem ] mutuo 22.63 modicos] leti 22.65 vana] una 22.68 videt] vidit $* 22.74$ gigneret] gignere 22.75] deest 22.77-ad finem] desunt

University of Ottawa 


\section{Notes}

For counsel and criticism, I am grateful to David Galbraith, Erika Rummel, James Carley, and William Stoneman; to Julian Conway, of the British Library's Department of Manuscripts; and to Harry Vredeveld, particularly, for his detailed scrutiny of my research and his willingness to make available to me typescripts of forthcoming work of his.

The paper and notes use the following abbreviations: Allen = P.S. Allen, H.M. Allen and.H.W. Garrod, eds., Opus Epistolarum Des. Erasmi Roterodami, 12 vols. (Oxford, 1906-1958); $C E=$ Peter G. Bietenholz and Thomas B. Deutscher, eds., Contemporaries of Erasmus, 3 vols. (Toronto, 1985-1987); CWE = Collected Works of Erasmus, vols. 1(Toronto, 1974-); Ferguson= Wallace K. Ferguson, Erasmi Opuscula: $A$ Supplement to the Opera Omnia (The Hague, 1933); Reedijk = Cornelius Reedijk, ed., The Poems of Desiderius Erasmus (Leiden, 1956); Smith = Preserved Smith, Erasmus: A Study of his Life, Ideals and Place in History (1923, rpt. New York, 1962); and Vredeveld, "Erasmus' Poetry" = Harry Vredeveld, "Towards a Definitive Edition of Erasmus's Poetry," Humanistica Lovaniensia 37 (1988), 115-174.

1. Gore Vidal, "Tennessee Williams: Someone to Laugh at the Squares With," in At Home; Essays 1982-88 (New York, 1988), p. 52.

2. Examples - from Ovid to Shakespeare - are too many to be enumerated; only writers whose literary remains are poorly attested still appear to be exceptions. The revision of the Eclogues of Mantuan - a leading neo-Latin poet of the period during which Erasmus was seeking to make a name for himself in the same field - has been graphically documented lately, be Lee Piepho, "Mantuan and Religious Pastoral: Unprinted Versions of his Ninth and Tenth Eclogues," Renaissance Quarterly 39 (1986), 644-672, and "Mantuan on Women and Erotic Love: A Newly Discovered Manuscript of the Unprinted Version of his Eclogues," Renaissance Studies 3 (1989), 13-28.

3. This thesis has recently been discussed by Bernard Cerquiglini, Eloge de la variante (Paris, 1989), esp. pp. 18-29; cf. also Alvin Kernan, Printing Technology, Letters and Samuel Johnson (Princeton, 1987), pp. 48-55.

4. As in the instances - characteristically involving some societal interest in maintaining authority - of law, Scripture, patristic and other authorities for religious dogma, and, intermittently, the classics.

5. A striking illustration is embodied in the texts of Pietro Carmeliano's Beatae Katerinae Vita, written 1483-1485. Carmeliano published his work by means of three presentation copies, two of which survive (Cambridge, Gonville and Caius College, Ms. 196/102; and Oxford, Bodleian Library, Laud Misc. 501). Even in details of decoration and mise-en-page, the two surviving manuscripts are as alike as any two handmade things can be; and both are autograph copies, written by the poem's author for formal, final publication. The texts of Carmeliano's 635-line poem in the two manuscripts differ from one another in some seventy-five places, none of them involving errors, and over fifty of them substantive.

6. Cf. Margaret Mann Phillips, The 'Adages' of Erasmus (Cambridge, 1964), pp. 41-165. Sotheby's has recently brought to auction a copy of the 1523 Froben edition of the Adagia that should shed much light on the details of Erasmus's revisionary habits. In addition to manuscript corrections, the copy is said to contain some two hundred and forty additional passages, in Erasmus's hand, inscribed between lines, in margins, and 
on interleaved slips of paper; many, but not all, of these appear in the next edition of the Adagia, that of 1526. The copy is described, with numerous illustrations, in the catalogue of Sotheby's 20 November 1990 sale, Continental and Russian Books and Manuscript, Science and Medicine, lot 397, pp. 208-217.

7. The manuscript was described summarily in the Catalogue of Additions to the Manuscripts in the British Museum 1854-1875, vol. 2 (London, 1877), for 1854, p. 837; notice of it was published by Allen in 1922, as quoted below; in 1923, the three unique items in it were published by Smith, pp. 453-457, along with the manuscript's "Contestatio salvatoris" [9]; in 1933, Ferguson, pp. 25-31, republished the same items, excepting the non-Erasmian "Epigramma Gaguini," [4]; and the manuscript has been used by Reedijk for his 1956 edition of the poems, and by Vredeveld, "Erasmus" Poetry," for his castigationes of Reedijk.

8. The manuscript measures $280 \times 188 \mathrm{~mm}$, and does not appear to have ever been trimmed much, if at all; the writing occupies a single column, which is unruled, of between thirty-six and thirty-two lines, measuring c. $215 \times \mathrm{c} .145 \mathrm{~mm}$. It is made up of five conjugate bifolia, from a single stock of paper, gathered into a single gathering of ten leaves, from which nothing appears to be missing. I have been unable to identify the watermark in the paper; it would belong among Briquet's class "indéterminés," though it does not appear there. The nearest thing to it I have seen is Briquet no. 6702 (found in Northern Italian papers of c. 1489-1491), which is not in fact very much like. The statement that the manuscript is "illuminated," repeated by Allen, Smith, Reedijk, and others, is mistaken. For comparison with the hand of the manuscript, I have used the reproductions of Erasmian autographs in CWE, II, 130, and III, 152 and 212 (examples of 1507 and 1515, respectively); and reproductions of Cambridge, Trinity College, Ms. R.9.26 (an example of 1503) and Copenhagen, Kongelige Bibl., Gl. Kgl. Samling 96, made available to me by Erika Rummel, from whose advice about Erasmus's hand(s) I have benefitted.

9. For dating the composition of these items, I have relied on the discussions of Allen, for the data of [1], the letter, and on Reedijk's discussions in his headnotes to the several poems, except as indicated otherwise. The possible exceptions to the claim that all the manuscript's items antedate 1500 in composition are items [9] and [10]. [9], the "Contestatio salvatoris," was not printed or otherwise published until c. 1511, when it appeared, as the "Expostulatio salvatoris," in a form that differs greatly from the Egerton manuscript "Contestatio;" this difference is discussed below. Reasons for thinking that the "Contestatio" was written by 1500 are: first, that the "Expostulatio" appears to be an amplification of the "Contestatio," rather than the "Contestatio" appearing to be an abbreviation of the "Expostulatio," so that the "Contestatio" antedates the c. 1511 publication of the "Expostulatio;" and second, less certainly informative, that the "Contestatio" occurs in the Egerton manuscript. The claim that the composition of the manuscript's item [10], the "In laudem Anne," antedates 1500 is similarly somewhat ill-founded. Reedijk's reason for believing the poem to have been composed "c. 1489" - a passage in the letter Erasmus wrote to cover the poem's presentation to Anna van Borssele (Ep. 145), in which Erasmus describes it as "carmen vel rhithmos potius a me puero lusos" and claims "a tenellis unguiculis eius Divae pietate flagravi" - may be insufficient. The poem may in fact be nearly as late in composition as its date of presentation to Anna van Borssele, with Ep. 145, in late January, 1501; the best evidence here - but again, it is not good evidence - for a date 


\section{8 / Renaissance and Reformation}

of composition somewhat earlier than that of the poem's presentation to the Lady of Veere is the fact that the poem occurs in the Egerton manuscript, again in what appears to be draft form.

10. Others have made "etc." of the manuscript's curious, abbreviated scrawl at this point (cf. Vredeveld, "Erasmus' Poetry," p. 154), where I have read an abbreviation for "rebus."

11. In the Sotheby's sale catalogue for the second of the sales of Bright's books - the sale of his manuscripts, held 18 June 1844 (cf. Seymour De Ricci, English Collectors of Books and Manuscripts [Cambridge, 1930], p. 107 and n. 3) - Lot 15l (p. 18) is described as follows:

MISCELLANIES. Liber Theoduli cum commento - Aviani Fabulae, on vellum. XIIIth Century, damaged - Centones Probae, 1481 - Seb. Brant, In Thurcum invectiva - Jo. Franc. Pici Mirandulae Hymni. Carmen extemporale (ad Jo. Skeltonum), etc.

According to the annotated copy of this sale catalogue, prepared by Sir Frederic Madden and now in the British Library, this miscellaneous Lot 151 - consisting of a series of distinct manuscripts, independent in origin, no matter whether or not they were at the time bound as a single volume - was sold to the bookdealer Thomas Thorpe (for two pounds, eleven shillings).

Some years later, Alexander Dyce, who had published an edition of John Skelton's poetry shortly before the Bright sale, in 1843, and who would have had occasion to deal with Thorpe, printed a text of the "Ad Skeltonum carmen" (i.e., Reedijk, no. 46), in a second, somewhat augmented edition of his The Poetical Works of John Skelton (Boston, 1856), pp. Ixvii-lxviii. Dyce says that the text he gives was "transcribed from a MS. (in the collection of the late Mr. B.H. Bright, ) consisting of Hymni, \&c., by Picus Mirandula;" but, except for the fact that Dyce here entitles the poem "Pici Mirandulae Carmen Extemporale," his text appears to represent a transcription of the text in Egerton 1651, as Harry Vredeveld has shown me.

After its purchase by Thorpe in 1844, that portion of Lot 151 described in the catalogue of the Bright sale as "Jo. Franc. Pici Mirandulae Hymni. Carmen extemporale (ad Jo. Skeltonum), etc." seems to have come into the possession of Charles Frederick Molini, a resident of London, about whom I have been able to discover nothing, except that, by a letter of 16 November 1854, addressed to Madden and now among the minutes of acquisitions kept in the departmental records of the British Library (as described and later shown to me by Julian Conway, from whose advice I have benefitted much), Molini offered to sell to the Library a group of fifteen manuscripts, which he listed under the heading "Italian Mss." Among these is one that Molini described in his letter as "Mirandola $<$ e $>$ (Io. F. Pici) Hymni Heroici Tres - et carmen extemporale ad Skeltonum cum comment<0 $>-$ small folio, neatly written Ms of XVI. century" (for which he was asking nine shillings). These are nearly the same terms as were used in the Bright sale catalogue, and the gist of them was at some point written in pencil, vertically, in the inner margin of the first folio of Egerton 1561.

In a memorandum of 24 November 1854, also kept among the departmental minutes of acquisitions, Madden noted that he had selected for purchase for the British Museum Library seven of the "Italian" manuscripts that Molini was offering; the seven became Egerton Mss. 1649-1655. By the time the catalogue of these acquisitions came to be 
printed, it had been established that what had been sold as a manuscript of the poetry of the Italian, "Mirandolae (Io. F. Pici)," including the poem ostensibly by Pico "ad Skeltonum," and then accessioned as Egerton 1651, was in fact a collection of writings by Erasmus, not Pico.

12. Ed. Allen, 1, 6; CWE 1X, 299-300 (no. 1341a).

13. Allen, IV, xxi. Ferguson, pp. 25-26, H.W. Garrod, "Erasmus and his English Patrons," The Library, 5th ser., 4 (1949), 4-5, and Reedijk, p. 202, have concurred with Allen's view.

14. On the other hand, John Skelton seems to have presented his paean on the accession of Henry VIII to the king in 1509 in the form of a rather plain copy indeed, now London, P.R.O., E 36/228, fols. $7 \mathrm{r}-8 \mathrm{v}$ : a pair of ungathered sheets of paper, altogether undecorated, that were folded and endorsed like a letter. The copy is reproduced in P.J. Croft, Autography Poetry in the English Language (New York, 1973), I, 6-8. Likewise, there is an altogether plain and simple copy, again on paper, of a group of poems by Robert Whittinton, now Hatfield House, Cecil Papers 233/8, that may have been presented to Henry VIII in 1532.

15. Most telling of these perhaps is that, having copied out the poem in full once already, the copyist of the Egerton manuscript began to copy again at the end of the book Erasmus's poem in praise of Skelton [1 1], stopping here after only three lines, evidently having realized by then that a copy of the piece had already been taken.

16. Ep. 104; Allen, I, 239, 240.

17. See Paul L. Hughes and James F. Larkin, Tudor Royal Proclamations, vol. 1 (New Haven, 1964), 52-54 (nos. 46-47).

18. On Charnock, see $C E$, I, 300-301.

19. Ep. 112; Allen, I, 260.

20. p. 113; Allen, I, 261-265. Cf. Vredeveld, "Some 'Lost' Poems of Erasmus from the Year 1499," in Fide et Amore: A Festschrift for Hugo Bekker, ed. W.C. McDonald and Winder McConnell (Göppingen, 1990), p. 331.

21. Ep. 113; Allen, 1, 264-265.

22. Vredeveld would characterize these remarks about the "Prosopopoeia Britanniae" as "obligatory modesty" on Erasmus's part; as he points out, Erasmus did in fact have the poem printed frequently in the sixteenth century and he also mentions it among his other acknowledged writings in the Catalogus lucubrationum.

23. On the basis of this exchange of letters between Erasmus and Sixtinus, Vredeveld, "Some 'Lost' Poems," pp. 330-331, makes the same few inferences about the nature of what Sixtinus saw; he goes on to argue, pp. 331-337, that the collection seen by Sixtinus may have included also Reedijk nos. 19-21, which do not occur in the Egerton manuscript, in addition to the "In laudem Annae" (Reedijk no. 22) and the "Contestatio salvatoris" (Reedijk no. 47), which do. Reedijk, pp. 398-399, discusses the same correspondence more pessimistically, as regards what conclusions can be drawn from the evidence.

24. By the time of his departure from Paris in May 1499, Erasmus had seen printed only his De casa natalica collection of verse, two additional poems (Reedijk nos. 43 and 40) and a letter (Ep. 49) in Willem Hermans's Silva Odarum, and an additional letter 
(Ep. 49), printed and reprinted, in Robert Gaguin's De origine et gestis Francorum. On the printing of humanist writing in England at this time, see Carlson "Reputation and Duplicity: The Texts and Contexts of Thomas More's Epigram on Bernard André," forthcoming in $E L H$.

25. Allen, IV, xxi.

26. For bibliographical descriptions of these two volumes, see F. Vander Haeghen, R. Vanden Berghe, and Th. -J.-I. Arnold, Bibliotheca Erasmiana: Adagia (Gand, 1897), pp. 1-7 and 10-14; the edition of 1500 was simply reprinted by its publisher in 1505 , without editorial or authorial intervention.

27. Some of the printed versions' putative improvements may be only apparent, results of errors of the Egerton copyist rather than authorial revision; the absence in the Egerton manuscript of posse, from the phrase "nec quicqum omnino fortium virorum memoriam eternam reddere," for example, would seem to be an erroneous omission of the Egerton copyist rather than an improvement of the printed versions.

28. For readings of the printed texts of the various writings of Erasmus discussed here and below, I have often had to rely on the reports of Allen, Reedijk, and Vredeveld, "Erasmus' Poetry;" I have also had the pleasure of examining many of the pertinent printed books, in the collections of the Folger Shakespeare Library, the British Library, and the Centre for Reformation and Renaissance Studies, Toronto.

29. Catalogus lucubrationum; Allen, 1, 3-4.

30. Cf. the discussion of Reedijk, pp. 227-228. In the $C W E$ volume of Erasmus's poems (vol. 85, forthcoming), Vredeveld makes a case for dating the poem to the winter or early spring of 1491 .

31. The collection was printed and reprinted by Marchand during 1496, the first time probably fairly early in the year, the second time with some quantity of verbal and orthographical variation; cf. the discussion of Reedijk, pp. 237-238. For description of the two books, see the Gesamtkatalog der Wiegendrucke, vol. VIII (Stuttgart, 1978), nos. 9375-9376.

32. Described in Irmgard Bezzel, Erasmusdrucke des 16. Jahrhunderts in Bayerischen Bibliotheken (Stuttgart, 1979), no. 968.

33. Described in Bezzel, nos. 846, 848-849, and 850-851. The second of these editions, that of June 1516, adds to its title page the claim "Ex recognitione authoris." The description of these volumes in Reedijk's "Survey of Editions and Ms. Sources Containing Poetry by Erasmus,' p. 369, nos. 188-190, as omitting the poem's section on Raphael (Reedijk no. 36), is mistaken.

34. Described in Bezzel, nos. 912 and 852.

35. Cf. Vredeveld, "Erasmus' Poetry," p. 150.

36. Cf. also Vredeveld's castigationes of Reedijk's edition of these poems, "Erasmus' Poetry," pp. 150-152.

37. For the date, see Ep. 43 (and the comments on it in Allen, I, 145-146 and CWE, I, 83), a letter from Robert Gaguin replying to a no longer extant letter by which Erasmus is thought to have addressed to Gaguin a copy of his poem "Ad Gaguinum nondum visum" ([3], Reedijk no. 38). 
38. The epigram does not appear among the materials published by Louis Thuasne, Roberti Gaguini Epistole et Orationes, 2 vols. (Paris, 1903).

39. The variant at 38.3 , where the Egerton manuscript reads "trepideque pallideque" might be regarded, not as a substantive, but simply as an orthographical variant, except that the reading is in the manuscript corrected form "trepidaeque pallidaeque," the reading of the later printed editions, which the Egerton copyist here first wrote and then expunged.

40. Both the Egerton manuscript and the later printed editions also lack the heuristic apparatus that the 1496 editions provide for Erasmus's conversation with his muse ([5], Reedijk, no. 39), that is, the speech-cues "Thalia" and "Herasmus" (in the margin, iuxta 39.15 and 39.17 , respectively) and the interlinear explanation "Nam hoc carmen et ruri et autumno scriptum est" that follows 39.18. The title of the poem in 1496, "Carmen lyricum de hystoriis Roberti Gaguini atque eglogis Fausti. Inducit secum loquentem Faustinam musam" changes in the later editions to incorporate the interlinear explanation of the 1496 edition: "In annales Gaguini et eglogas Faustinas carmen ruri scriptum et autumno;" and the marginal speech cues disappeared. In general, such change seem more likely to be results of a printer's rather than an author's decisions: marginalia were more difficult (and so more costly) to do in print than in manuscript, and so would have seemed less worth introducing or reproducing to printers and their compositors than they would have seemed to scribes or to authors habituated to manuscript technology. The textually stable marginalia printed with the "Prosopopoeia Britanniae" in the sixteenth century (e.g., with the texts of the poem in the 1518 Froben Epigrammata and the 1506 Bade edition of Erasmus's translations Hecuba et Iphigenia, but not with the text in the subsequent Aldine edition of the same materials), mentioned only dismissively by Reedijk, p. 248 n., are probably authorial. Cf. Vredeveld, "Erasmus' Poetry," pp. 153 and 157-158.

41. Cf. Vredeveld, "Erasmus" Poetry," pp. 152-154.

42. On Caminade and his relations with Erasmus, see Franz Bierlaire, "Erasme et Augustin Vincent Caminade," Bibliothèque d'humanisme et renaissance 30 (1968), 357-62, and $C E$ 1, 280-281; on Hemmerlin, see $C E$, II, 175.

43. In the forthcoming $C W E$ volume, Vredeveld established July, 1498 as the date of the epigram.

44. On Skelton's tenure as a tutor in the royal household, see Carlson, "Royal Tutors in the Reign of Henry VII," forthcoming in The Sixteenth Century Journal.

45. See above, n. 7.

46. See Reedijk's discussion, p. 238.

47. The letter is Ep. 49, Allen, I, 160-164; for bibliographical description of the Hermans Sylva odarum, see the Catalogue of Book Printed in the XVth Century Now' in the British Museum, part VIII (London, 1949), 62-63.

48. The 1497 edition acknowledges its defectiveness in these passages, by leaving space blank on the page where the lines belonged.

49. Cf. also Vredeveld, "Erasmus' Poetry," pp. 154-156.

50. Cf. the discussions of Smith, p. 455, Ferguson, p. 28, who suggests that the poem may date from Erasmus's "conventual period," and Reedijk, p. 255. 


\section{2 / Renaissance and Reformation}

51. Cf. also 47.9 rogatus with 85.21 roganti.

52. For bibliographical description of the printed book, see M.E. Kronenberg, Nederlandsche Bibliographie van 1500 tot 1540, vol. 2 ('s-Gravenhage, 1940), 330, no. 2887; and see also the discussion of Reedijk, pp. 291-293.

53. Cf. Vredeveld, "Erasmus' Poetry," pp. 160-161.

54. Cf. Ep. 87-90 and 120, and the notes on them in Allen, I, 223 and 282-4 and CWE, I, 174 and 247.

55. Cf. $C E, \mathrm{I}, 100-101$ and 173-174.

56. Ep. 145; Allen, I, 345.

57. In the forthcoming $C W E$ volume, Vredeveld argues for a date of late 1490 or early 1491 for the first version of the poem.

58. Reedijk misreports the variants at the poem's conclusion, in such a way as to suggest that the Egerton manuscript text is defective, a faulty representation of something transmitted accurately only in print. He reports that the manuscript simply ends with 22.76; i.e., that it includes the portending question (22.75) but no more than a line of answer to it (22.76) before giving out. In fact, it omits the interrogatory line (22.75) but not the next one, which in the manuscript supplies an object for the very "gigneret" (22.74), to conclude its text of the poem. Cf. Vredeveld, "Erasmus' Poetry," p. 144.

59. Cf. also Vredeveld, "Erasmus' Poetry," pp. 143-144. 